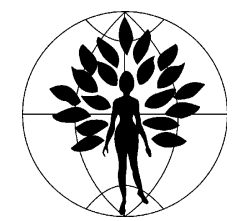

\title{
CA 125 half-life breakpoint between a "good" and "poor" prognosis in patients with ovarian cancer
}

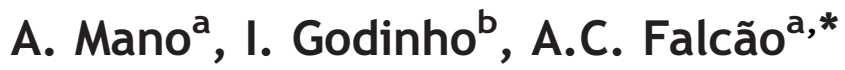 \\ a Laboratory of Pharmacology, Faculty of Pharmacy, University of Coimbra, 3000-295 Coimbra, Portugal \\ ${ }^{\mathrm{b}}$ Gynaecology Service, Coimbra University Hospital, Coimbra, Portugal
}

Received 13 September 2004; received in revised form 28 December 2004; accepted 28 December 2004

\section{KEYWORDS \\ CA 125; \\ Tumor markers; \\ Ovarian cancer}

Ovarian cancer, generally treated with combination first line chemotherapy after cytoreduction surgery [1], has the highest mortality of all invasive cancers of the female reproductive system. CA 125 serum concentration is usually adopted to evaluate the clinical situation in ovarian cancer patients [2]. An approach to rapid evaluation of clinical response and monitoring, instead of using the coarse CA 125 serum concentration, is the determination of tumor marker kinetic parameters, associated with changes in its concentrations, such as half-life $\left(t_{1 / 2}\right)$ and doubling time (DT) [3]. The rate of decline in CA 125 during primary chemotherapy has been an important independent prognostic factor in several multivariate analyses [2]. Several studies report the greatest difference in progression rate, found at a $t_{1 / 2}$ of 20

\footnotetext{
* Corresponding author. Tel.: +351 239 855092; fax: +351 239 855099.

E-mail address: acfalcao@ff.uc.pt (A.C. Falcão).
}

days while the normal CA 125 half-life value to be determined varied from 5 to 10 days $[3,4]$.

The aim of the present work is the determination of CA 125 half-life breakpoint between a "good" or "poor" prognosis in our population. Retrospective clinical information was obtained from 339 patients with a diagnosis of ovarian cancer at the Gynaecology Service of Coimbra University Hospitals (CUH) main database from 1990 to 2000 . Only 63 patients (mean age: 58.5 years old, range $16.3-82.4$ years) were included in the present analysis due to the restriction of our inclusion criteria: patients that underwent primary line chemotherapy within 3 months after submission to cytoreductive surgery. Six patients had FIGO stage I; five had stage II; fortyone had stage III; seven had stage IV and in four patients this information was missing. Fifty-eight had epithelial ovarian cancer; four patients have other histological types and one patient with no information. None borderline tumor was include. Seven patients had a tumor grade 1; twenty-two a tumor grade 2; nine had a tumor grade 3 and twentyfive patients had no tumor grade information. The mean duration of primary chemotherapy was 4.2 $(0.7-10.2 ;$ S.E. $=0.2)$ months: twenty-seven patients had a complete response to primary chemotherapy;

0020-7292/\$ - see front matter (C) 2005 International Federation of Gynecology and Obstetrics. Published by Elsevier Ireland Ltd. All rights reserved.

doi:10.1016/j.ijgo.2004.12.028 
Table 1 Overall survival for the different prognostic group concerning the $t_{1 / 2}$ breakpoint

\begin{tabular}{|c|c|c|c|c|c|}
\hline $\begin{array}{l}\text { CA } 125 \\
t_{1 / 2} \text { (days) }\end{array}$ & Classification & $N$ & $\begin{array}{l}\text { Mean overall } \\
\text { survival (SD) } \\
\text { [months] }\end{array}$ & $\begin{array}{l}\text { Median overall } \\
\text { survival }\left(Q_{25}-Q_{75}\right) \\
\text { [months] }\end{array}$ & $p$-Value \\
\hline \multirow[t]{2}{*}{10} & Good $\left(t_{1 / 2} \leq 10\right.$ days $)$ & 4 & 47.7 (33.7) & $39.7(23.8-71.5)$ & $p=0.2149$ \\
\hline & Poor $\left(t_{1 / 2}>10\right.$ days $)$ & 59 & $28.8(19.8)$ & $22.6(13.4-44.1)$ & \\
\hline \multirow[t]{2}{*}{15} & Good $\left(t_{1 / 2} \leq 15\right.$ days $)$ & 10 & $39.5(24.4)$ & $31.6(22.3-48.9)$ & $p=0.1058$ \\
\hline & Poor $\left(t_{1 / 2}>15\right.$ days $)$ & 53 & $28.2(20.2)$ & $21.5(11.8-44.1)$ & \\
\hline \multirow[t]{2}{*}{20} & Good $\left(t_{1 / 2} \leq 20\right.$ days $)$ & 24 & $38.8(22.1)$ & $34.7(21.9-51.4)$ & $p=0.0069$ \\
\hline & Poor $\left(t_{1 / 2}>20\right.$ days $)$ & 39 & $24.5(18.7)$ & $18.7(9.4-35.6)$ & \\
\hline \multirow[t]{2}{*}{25} & Good $\left(t_{1 / 2} \leq 25\right.$ days $)$ & 32 & $38.7(21.3)$ & $35.3(21.9-54.3)$ & $p=0.0003$ \\
\hline & Poor $\left(t_{1 / 2}>25\right.$ days $)$ & 31 & $21.0(16.9)$ & $17.2(9.0-27.7)$ & \\
\hline \multirow[t]{2}{*}{30} & Good $\left(t_{1 / 2} \leq 30\right.$ days $)$ & 40 & $37.4(21.8)$ & $34.7(20.4-54.3)$ & $p=0.0001$ \\
\hline & Poor ( $t_{1 / 2}>30$ days $)$ & 23 & $17.1(11.8)$ & $16.9(8.6-21.5)$ & \\
\hline \multirow[t]{2}{*}{35} & Good $\left(t_{1 / 2} \leq 35\right.$ days $)$ & 42 & $36.5(21.7)$ & $33.5(19.4-54.0)$ & $p=0.0002$ \\
\hline & Poor $\left(t_{1 / 2}>35\right.$ days $)$ & 21 & $16.9(12.0)$ & $16.9(8.6-19.0)$ & \\
\hline \multirow[t]{2}{*}{40} & Good $\left(t_{1 / 2} \leq 40\right.$ days $)$ & 44 & $35.9(21.4)$ & $31.6(19.4-51.4)$ & $p=0.0002$ \\
\hline & Poor $\left(t_{1 / 2}>40\right.$ days $)$ & 19 & $16.4(12.5)$ & $15.4(6.2-19.0)$ & \\
\hline \multicolumn{6}{|c|}{ Between $t_{1 / 2}=16$ and $t_{1 / 2}=19$ days statistically significant difference was first found for $t_{1 / 2}=16$ days } \\
\hline \multirow[t]{2}{*}{16} & Good $\left(t_{1 / 2} \leq 16\right.$ days $)$ & 14 & $43.5(24.3)$ & $34.8(22.3-66.9)$ & $p=0.0086$ \\
\hline & Poor $\left(t_{1 / 2}>16\right.$ days $)$ & 49 & $26.1(18.6)$ & $19.3(11.4-35.8)$ & \\
\hline
\end{tabular}

(All patients with $t_{1 / 2} \leq 0$ were classified as "good").

eighteen had a partial response; fourteen had no response or a disease progression and four patients had missing information. At evaluation date, fortythree patients were deceased while twenty-three were alive. The mean overall survival was 30.0 (1.96-94.2; S.E.=2.7) months.

For each patient, we determined the CA 125 half-life using the formula:

$t_{1 / 2}=\frac{(\ln 2)\left(t_{2}-t_{1}\right)}{\ln \left(\frac{c_{1}}{c_{2}}\right)}$

where $C_{1}$ is the first CA 125 serum concentration after cytoreduction surgery (must be superior to the $35 \mathrm{lU} / \mathrm{ml}$ cut-off), $C_{2}$ is the first CA 125 serum concentration below $35 \mathrm{IU} / \mathrm{ml}$ or the last CA 125 concentration after five CA 125 normal half-lives (50 days) in case CA 125 did not normalize below $35 \mathrm{IU} / \mathrm{ml}$, and $t_{1}$ and $t_{2}$ are the corresponding dates for $C_{1}$ and $C_{2}$ respectively. Regarding the half-life value the patient's prognosis was classified into two classes: "good" or "poor" prognosis if $t_{1 / 2} \leq X$ or $t_{1 / 2}>X$ respectively, where $X$ is equal to $10,15,20,25,30,35$ or 40 days. All patients with $t_{1 / 2} \leq 0$ were classified as "poor." A statistical analysis was conducted and the Mann-Whitney $U$ test was used to compare the overall survival across subgroups of patients depending on CA 125

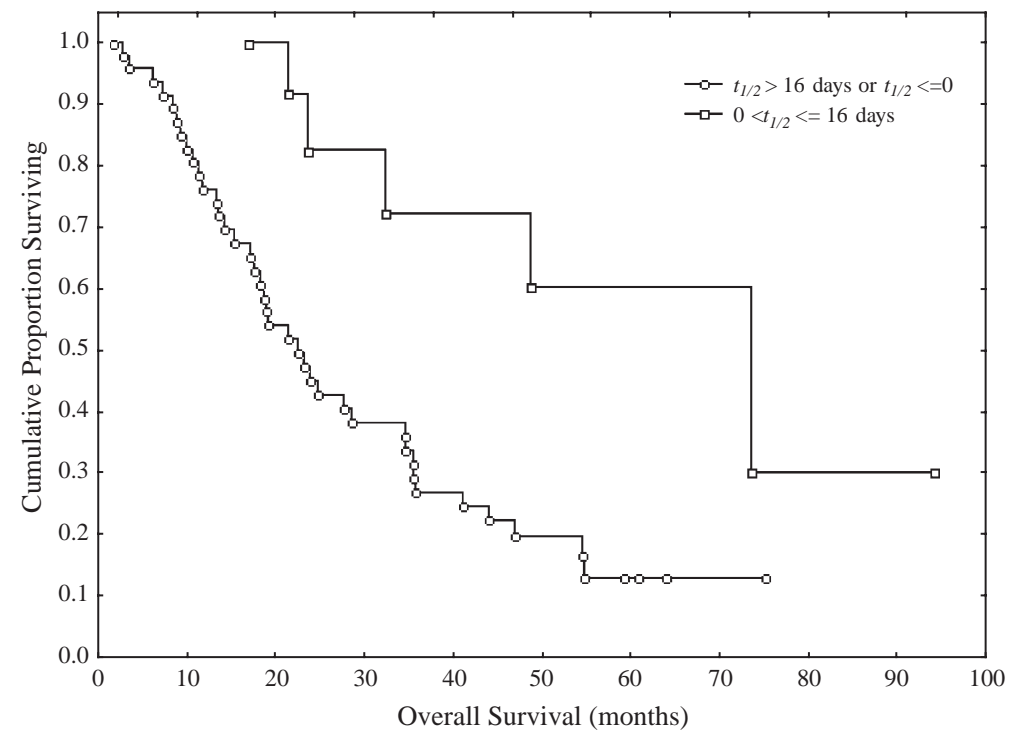

Figure 1 Kaplan-Meier curve according with CA 125 half-life breakpoint of 16 days between a "good" $\left(0<t_{1 / 2} \leq 16\right.$ days) and a "poor" $\left(t_{1 / 2}>16\right.$ days or $\left.t_{1 / 2} \leq 0\right)$ prognosis. 
$t_{1 / 2}$ behavior ( $p \leq 0.05$ was considered statistically significant) (Table 1). Fig. 1 shows the survival curve (Kaplan-Meier) in agreement with CA 125 half-life breakpoint of 16 days.

Čolaković et al. [4] reported that patients with a CA 125 half-life $<20$ days had 1.8 times longer survival times than those with a longer CA 125 half-life while in our study the obtained breakpoint was 16 days and patients with CA 125 half-life below this value have a mean survival 1.67 times greater than others with longer CA 125 half-life values. Nevertheless, the existence of CA 125 half-life breakpoint to allow the discrimination between "good" or "poor" prognosis confirms the suitability of this kinetic parameter for an earlier prediction of the patient's overall survival. However, the CA 125 half-life kinetic parameter should not be used alone but in combination with other recognized prognostic factors.

\section{Acknowledgments}

This work was financially supported by a grant (Praxis XXI/BD/3248/2000) from FCT (Fundação para a Ciência e a Tecnologia).

\section{References}

[1] Baker VV. Treatment options for ovarian cancer. Clin Obstet Gynaecol 2001;44(3):522-30.

[2] Bast Jr RC, Xu FJ, Yu YH, Barnhill S, Zhang Z, Mills GB. CA 125: the past and the future. Int J Biol Markers 1998;13(4): 179-87.

[3] Bidart JM, Thuillier F, Augereau C, Chalas J, Daver A, Jacob $\mathrm{N}$, et al. Kinetic of serum marker concentrations and usefulness in clinical monitoring. Clin Chem 1999;45(10): $1695-707$.

[4] Čolaković S, Lukiç V, Mitroviç L, Jeliç S, Šušnjar S, Marinkoviç J. Prognostic value of CA 125 kinetics and half-life in advanced ovarian cancer. Int J Biol Markers 2000;15(2): $147-52$. 